\title{
Teachers' Reinforcement on Students' Behavior in English Teaching Process at the First Grade Sudents of SDIT PadangIslamic School in Academic Year 2018/2019
}

\author{
Rosi Kumala Sari \\ Universitas Putra Indonesia YPTK Padang, Indonesia \\ Rosikumalasari0705@gmail.com
}

\begin{abstract}
This study was a descriptive study aimed at describing the implementation of reinforcement used by English teacher to the students on the first grade of SDIT Padang Islamic School, Gunung Pangilun Padang. The subjects of this study were an English teacher and 24 students. The data of this study were collected by observation and interview. The result of this study showed that the English teacher on the first grade of SDIT Padang Islamic School, Gunung Pangilun Padang used various kinds of reinforcement such as verbal, gestural, contact, and proximity reinforcement. Positive and negativereinforcement were consisted by each of those types. For positive reinforcement, the teacher used "good, very good, well done, good enough, that"s right, nice, smiling, nodding head, thumb up, applause, touching the students, standing next to the students, and sitting close with the students". For negative reinforcement, the teacher used "sssst, calling students" name, giving warning, giving explanation, and putting forefinger in front of the lips". Besides, the teacher also apply it enthusiasticly.
\end{abstract}

Keywords: Finger, Reinforcement, Academic, School

\section{Introduction}

Good teaching process can change students' behaviour into positive one. The best positive behaviour is formatted from at an early age of the students (Prasetyo, 2011). It includes english teaching process for young learner. Teaching English for young learners may be challenging since young learners tend to have boundless physical energy, have short attention span, easily to get bored and unpredictable (Qinglan, Junyan, \& Shongshan, 2003). Because of that, the English teachers for young learner have to have the ability to manage the class, so that the students can get interesting in learning. Interest learning process can be created by managing the class effectively. According to Kyriacousokal, et.al in (Rubio, 2010), classroom management seems to be the high priority for beginner. Beside, the experience teachers is needed in teaching English for young learners (Qinglan et al., 2003). Classroom management is defined as the teachers' ability to manage time, students' involvement, students engagement, coordinate classroom resources and space, and manage students' behavior (Coe, 2014). Effective classroom management is related to reinforcement since giving reinforcement to the students is one of the classroom management tool
(Knoster, 2014). According to Hapsari \& Widhianningrum (2016) "Reinforcement is a response to a behavior that increases the likelihood of recurrence." In the learning process, provision of reinforcement is a form of positive response of teachers to the behavior of students so that student behavior can be repeated again at a later time. By designing the environment of the class properly, the students can be motivated to learn. Reinforcement is one factor to create a good environment of teaching process in the class. Reinforcement can occur in two ways, which are called negative reinforcement and positive reinforcement (Skinner in (Weeite, W., 2015). Negative reinforcement results when an undesirable consequence is held to strengthen the behavior to be repeated. Negative reinforcement is different from punishment, in which negative reinforcement is used to discourage the undesirable behavior, however punishment is used to decrease the probability of specific behavior (Kearns, 2014).

However, positive reinforcement results when the occurrence of desirable behavior tostrengthen the behavior to be repeated (Skinner in Weeite, et.al, 2015:45). According to Skinner in Diedrich (2010), positive reinforcement is more effective than negative reinforcement as a 
classroom management. So teachers should be focus use positive reinforcement in managing the class. When the class is managed well, the learning process will run successfully. Acoording to (Coe, 2014) also adds that by giving positive reinforcement, itcan help the teacher to establish a classroom environment and manage the class where all students feel safe, comfortable and welcome, so it can encourage students' learning and prevent the occurrence of problems behavior. . In line with that, Dyah, Artini and Hery (2013) state that giving positive reinforcement to the students was able to build character building. In other words, using positive reinforcement in teaching english process can format the positive students' behaviour. Then, positive reinforcement can increase students' interest to love learning procees because the students feel confortable situation in the class. Then, through positive reinforcementteacher reinforce them to repeat the students' positive behavior. Thus, it is clear that, the reinforcement used by the teachers should have clear purpose and based on what have been done by the students. Giving reinforcement with clear purpose and in accordance with what have been done by the students will lead them to be highly motivated to learn and do, repeat and improve their positive behavior and achievement (Guendouze, 2012).

When reinforcement is rightly on target, the class will be managed well. Because of that a teacher needs positive reinforcement strategy, so the use of positive reinforcement will be given specifically, systematically, consistently and match to the have been done by the students. Positive reinforcement strategy defines as system, procedures and process that used by the teacher to apply positive reinforcements in the class (Cotton, 1988). In other words, the reinforcement that will be given should be well prepared, well organized, well implemented. Based on the results of class observation, the English teacher of SDIT Padang Islamic

School used positive reinforcement in managing classroom. The teacher gave the positive reinforcement to the students to encourage the students to love learning English and to reward the good behavior done by the students. However, in giving positive reinforcement to the students, the teacher did not implement positive reinforcement strategy. It showed through the use of monotonous verbal reinforcement and the teacher did not specify on what behaviors were being reinforced, for instance, she used "good" praise for mostly all good behavior done by the students. The result of the observation might be related to the teacher' limited strategies in giving reinforcement. The problem above contradicts to the theory of giving positive reinforcement, in which the positive reinforcement should be given specifically, systematically and based on what have been done by the students. Meanwhile, the object of the research was the teacher's guide for using positive reinforcement strategy for TEYL.

\section{Research Method}

The data were collected by using observation and interview. Firstly, in relation to need analysis, observation was used to collect the data of the use of positive reinforcement by the teacher and the content needs to be developed in the teacher' guide in using positive reinforcement strategy. Through observation technique, the researcher filled the observation sheet while observing the positive reinforcement strategy used by the teacher. Secondly,interview was done to gain data of need analysis. The researcher interviewed the english teacher. The researcher interview the English teacher by asking seven questions. The data collected in this research were analyzed qualitatively. According to (Given, 2008), qualitative method is research method that obtain descriptive data in the form of word series. Then the data gained from observation and interview were analyzed qualitatively. The data collected was translated from Bahasa into English, edited and presented into table. After that, the data were interpreted and the conclusion were drawn. The suggestions given were analyzed qualitatively by translating from Bahasa into English and presented descriptively.

\section{Result and Discussion}

Based on observation, the researcher found that the English teacher used both positive and negative reinforcement. Although the teacher use both of them, but researcher can observ, the english teacher use positive reinforcement dominantly for the first grade students of SDIT Padang Islamic School.According to (Hoque, 2013), giving positive reinforcement to the students gave positive contribution to the students' affective, cognitive and psychomotor aspects. In line with that, this study was focused only on positive reinforcement because through positive reinforcement, it would stimulate the students to redo their positive behavior. (Hoque, 2013) It also added that the use of various kinds of positive reinforcement would increase the meaning of certain reinforcemen Then, the observations were aimed at describing how the teacher used positive reinforcement when teaching in the classroom. The verbal reinforcement that seemed to be monotonous used by the teacher, like of "very good" every time when the students were able to finish their work on time, when they were participating in the class, or when they were able to perform in front of the class. Then, based on the 
observations, the researcher was found that the English teacher use verbal and nonverbal reinforcement. Next, the researcher also found that, some students tend to repeat some positive behaviour in the next time. In other hand, most of the students keep silent, when the teacher give negative reinforcements, such as ssst, put the fore finger on the lips, and speak some sentences to advise the students' mistake. In line with this, it showed that the teacher did not make any plan, do reflection after giving reinforcement, however, according to (Morgan, 2009); (Years, 2014) that before giving reinforcement to the students, the teacher needed to make a reward plan in order to lists the target behavior and reinforcement that would be used and a track reflection should be made by the teacher after giving reinforcement in order to remind about what has been done by the teacher and to know the teacher' self-strengths, self-weaknesses and the next movement. The second questionnaire was used to know the teacher' guide needed to be developed in the product.

Besides observation, the researcher were also interviewed to the English teacher. There were 3 questions given to the english teacher. The results from the first question showed that the teacher used both positive and negative reinforcement everyday. In other hand, she used positive reinforcement dominantly. The positive reinforcement given by the teacher was verbally and nonverbally. The teacher used various positive reinforcement such as good, very good, nice, give smile, rise thumb. In other hand the teacher used negative reinforcement, by giving some sign on the white board, like sad star, sssst, and put fore finger on two lips. Then sometime, teacher also speak some statements for explaining the students' mistake. Next, researcher also found, the teacher were not consistent in using reinforcement, when doing teaching english in the class. It means the teacher did not have good planning and less experience to build the

students' behaviour in the teaching process through using reinforcement. So, the students were difficult to understand the meaning of teachers' reinforcements. However, (Morgan, 2009) and (Years, 2014) state giving reinforcement in order to remind about what has been done by the teacher to praise the students'behaviour in teaching english process. Besides, It also to encourage the students to repeat their positive behaviour in the next movement. Therefore, the teacher need to know the strength and weaknesses of the reinforcement.

The second question related to the students' behaviours that the teacher hope to be done by the first grade students of SDIT Padang Islamic School, Gunung Pangilun Padang. Based on the interview, the researcher knows some behaviors are; the students keep silent, when the teacher speak up, the students say greeting before entering the class, the students speak up one by one in the class, and students may not noisy in the class. Based on the interview, the researcher found that, it is not easy to habit four behaviours to the first grade students of SDIT Padang Islamic School, Gunung Pangilun Padang. To format the students have four kinds of behaviour, the English teacher have to remember the students about the behaviour. Before starting the lesson inthe class, the English teacher repeat the behaviours. It need long time. The teacher said that, it is more than one semester. Beside, not all of the students can apply the four behavious in teaching process. Some of them can apply it almost one year. The change of behaviour can be seen when the students sit on the second grade. It line with this, (Prasetyo, 2011) states, to build the students behaviour is not easy, it is like paint the wood. It means the students' behaviour formation can not do in short time. It can be done slowly, patiently, consistently and clearly. According to Irawati, 2005, using the reinforcement in the teaching procees have to be clear regulation, need procees, and totality. In line with that (Kennedy, 2008) states using reinforcement is not priority to the result but process. It means that, to format the students' behaviour by using the reinforcement in the classs need long time, consistent and clear regulation in it's process. Next, the teacher said that, each of studnets has differerent time to understand and apply of each behaviour. There 5 students can understand and apply it after two monts. It is the shorthest time among them. The researcher ask the clear information from the homrome teacher that the five students are also get controll from their parent beside English teacher. And then the researcher get other information that the all of the teachers in SDIT Padang Islamic School also use the rehinforcemet for the same behaviour. It indicates that the school is serioully move the students' behaviour by using the reinforcement. Then 11 students can apply them is more than one semester. And the others can apply almost one year. It was done generally, since to move the behaviour need long time, consistent and clear regulation in using the reinforcement.

After that, to move students' behaviour by using the reinforcement need the organization concept, followed by aims, kinds and examples and procedures of each reinforcement types. The teacher needed guide in order to make it easier for use it in the teaching process. A good teacher' present thepositive and negative reinforcement systematically. It made the reinforcemnts are easy 
to be used, understeand and able to stimulate the students in teaching english process.

\section{Conclusion}

Reinforcement used by the teacher to the first grade studnets of SDIT Padng Islamic SChool are in good category. It is based on indicators such as verbal reinforcement, gestural reinforcement, activity reinforcement, approaching reinforcement, touch reinforcement, and sign reinforcement. The tEnglish teacher used the simple word, so the students can undertand easily. In otherhand, the English teacher has to be pay attention to use the reinforcement consistently and give clear regulation in using reinforcement. Next, each of students has different time to understand and apply the certain behaviour by using the reinforcement. Therefore the Englishteacher has to be patient, seriousand has good planning in using reinforcement in formating the students' behaviour. Then, to move the behavior can not be donein same time for many behaviour. It have to be done one by oneand step by step. Using reinforcement to move the behaviour need a process not product.

\section{References}

[1] Coe, R. (2014). What makes great teaching?: Review of the underpinning research. England: Durham University.

[2] Guendouze, M. (2012). the Effects of Anticipation Rewards on Students Motivation. Constantine University.

[3] Hamalik, Oemar. 2001. Proses belajar Mengajar. Bandung: Bumi Aksara

[4] Hapsari, P., \& Widhianningrum, P. (2016). Pengaruh Praktik Pengalaman Lapangan Terhadap Kinerja Mahasiswa Calon Guru.

[5] Hoque, S. R. (2013). " Effect of Reinforcement on Teaching - Learning Process ." IOSR Journal of Humanities and Science, 7(1), 13-16.

[6] Kearns, K. (2014). The big picture. Australia: Cengage Learning

[7] Kennedy, Christina., Jolivette, Kristine. (2008). The Effects of Positive Verbal Reinforcementon the Time Spent Outside the Classroom for Students With Emotional and Behavioral Disorders in a Residential Setting. 211-221.

[8] Knoster, T. (2014). The Teacher's Pocket Guide for Effective Classroom Management |. London: Brooks Publishing.

[9] Morgan, N. (2009). Quick, Easy and Effective Behaviour Management Ideas for the Classroom. UK: Jessica Kingsley Publishers.

[10] Prayitno, Iwan. Anakku Penyejuk Hatiku. Bekasi: Pustaka Tarbituna

[11] Qinglan, L., Junyan, W., \& Shongshan, H. (2003). Effective Classroom Management In Young Learners English Teaching. An Article of Shijiazhuang Mechanical Engineering College. 